\title{
Hydrochemical characterization of groundwater in around Tirupati Area, Chittoor District, Andhra Pradesh, South India
}

\author{
E. Balaji ${ }^{1}$ A. Nagaraju ${ }^{1}$ Y. Sreedhar ${ }^{1}$ A. Thejaswi $^{2} \cdot$ Zahed Sharifi $^{3}$
}

Received: 31 January 2014/ Accepted: 15 July 2016/Published online: 1 August 2016

(c) The Author(s) 2016. This article is published with open access at Springerlink.com

\begin{abstract}
In the management of water resources, quality of water is just as important as its quantity. The main aim of this study has been to assess the variability of groundwater parameters to develop water quality of Tirupati area and its suitability for domestic and irrigation purpose. Further, the samples were analyzed for $\mathrm{pH}$, EC, TDS, carbonates, bicarbonates, alkalinity, chlorides, sulfates, hardness, fluoride, calcium, magnesium, sodium, and potassium. Based on the analytical results, chemical indices like percent sodium, sodium absorption ratio (SAR), adjusted SAR, percent sodium (Na \%), residual sodium carbonate (RSC) and permeability index (PI) have been calculated. Chadha rectangular diagram for geochemical classification and hydrochemical processes of groundwater indicated that most of waters are $\mathrm{Ca}-\mathrm{Mg}-\mathrm{HCO}_{3}$ and $\mathrm{Ca}-\mathrm{Mg}-\mathrm{Cl}$ types. Assessment of water samples from various methods indicated that majority of the water samples are suitable for domestic and irrigation purpose.
\end{abstract}

Keywords Groundwater quality · Irrigation · Base-exchange indices - Gibbs ratio - Tirupati . South India

A. Nagaraju

arveti@yahoo.com

E. Balaji

balajiyvu@gmail.com

1 Department of Geology, Sri Venkateswara University, Tirupati 517 502, India

2 Environmental Sciences, School of Distance Education, Kakatiya University, Warangal 506 009, India

3 Department of Soil Science, College of Agriculture, University of Kurdistan, Sanandaj, Iran

\section{Introduction}

Water, is going to be polluted day by day with increasing urbanization (Alshikh 2011). About $70 \%$ of the earth's surface is covered with water. Ninety-seven percent of the water on the earth is salt water. Two percent of the water on earth is glacier ice at the North and South Poles. Less than $1 \%$ of all the water on earth is fresh water that we can actually use (Gleick 1993). We use this small amount of water for drinking, transportation, heating and cooling, industry, and irrigation and many other purposes. On the other hand, rivers play a major role in assimilation or transporting municipal and industrial wastewater and runoff from agricultural land (Shrestha and Kazama 2007). Although surface water resources are used to meet the growing municipal demands due to over contamination, more stringent treatments would be required to make the surface water potable (Hall and Ellis 1985; Kankal et al. 2012). The major hazard in drinking water supplies is due to contamination from agricultural runoff and improper storage and handling of water (WHO 2006; Saha et al. 2006; Nagaraju et al. 2006). Groundwater is a valuable resource and being depleted day by day (Alley et al. 1999). The gradual depletion of groundwater resources is making communities switch to surface water and/or conjunctive use (Stephen et al. 2013). Due to rapid urban-industrialization, extension of irrigation, domestic needs, groundwater demand has tremendously increased in the Tirupati area. Earlier researchers have studied about groundwater quality of nearby areas of Tirupati (Dilli Rani et al. 2011;Janardhana raju and Krishna Reddy 2006; Nagaraju et al. 2014). Groundwater is the important source for domestic purpose for more than $70 \%$ of the population in this area (Human Development Report of Andhra Pradesh 2007). The bore wells are major groundwater based

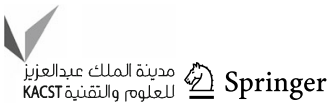


structures used for the exploration of groundwater (Jasmin and Mallikarjuna 2013).

Chemistry of groundwater plays an important role in the study of groundwater quality (Hem 1985). Variations in the major ion chemistry of groundwater lead to identification of geochemical processes that control the groundwater quality (Sadashivaiah et al. 2008; Ravikumar et al. 2011; Srinivas et al. 2013). Ion exchange involves the replacement of ions adsorbed on the surface of fine grained materials in aquifers by ions in solution. Groundwater quality depends on the nature of rock formation, topography, soils, atmospheric precipitation, environment, quality of recharged water, and on subsurface geochemical processes. In view of the complexity of factors determining water quality, and the large choice of variables used to describe the status of water bodies in quantitative terms, it is difficult to provide a simple definition of water quality. Furthermore, our understanding of water quality has evolved over the past century with the expansion of water use requirements and the ability to measure and interpret water characteristics. To the best of our knowledge no hydrogeochemical investigation has been performed to delve into groundwater quality in and around Tirupati area. Hence, this work aims to confine about the hydrogeochemical investigation mainly focusing to identify groundwater geochemistry and its suitability for drinking and irrigation purposes. The main objective is to develop an understanding of regional groundwater quality as an aid to better knowledge of the groundwater regime for optimal management of groundwater resources.

\section{Study area}

Tirupati lies between $13^{\circ} 37^{\prime}$ and $13^{\circ} 40^{\prime}$ North latitude and $79^{\circ} 21^{\prime}$ and $79^{\circ} 26^{\prime}$ East longitude (Fig. 1). This is situated in Chittoor district of Andhra Pradesh, South India. Occurrence, movement and storage of groundwater are influenced by lithology, thickness and structure of rock formations. The chemical composition of groundwater results from the geochemical processes occurring as water reacts with the geologic materials which it flows (Appelo and Postma 1996). Main hydrologic formations in Tirupati area consist of weathered and fractured granites and quartzites. Ground water in the study area occurs under water table conditions in the weathered and fractured granites. Monsoon remains moderate and summer experiences temperatures ranging from 35 to $44{ }^{\circ} \mathrm{C}$. In winter the minimum temperature is between 18 and $20{ }^{\circ} \mathrm{C}$ Celsius (Janardhana raju and Krishna Reddy 2006). In general summer spans from March to June, followed by the monsoon in July, followed by winter lasting through February.

\section{Materials and methods}

The sampling bottles were pre-conditioned with $5 \%$ nitric acid and later rinsed thoroughly with distilled de-ionized water. Sample bottles were also rinsed with actual water samples at each bore well before collecting samples. A total of fifty groundwater samples from bore wells have been collected during post-monsoon season of 2012. $\mathrm{pH}$ and electrical conductivity of the water samples were measured in situ using portable water analysis kit (P-30 Series Hand-held Water Quality Meters for $\mathrm{pH}$ and conductivity-Analyticon Instruments Corporation, USA). The cations and anions were analyzed using standard methods (Trivedy and Geol 1986; APHA 2005; Mishra et al. 2012; Tripathi et al. 2012).

The following diagrams were constructed to find out the different facies present in groundwater of this study.

\section{Hydrochemical facies for groundwater}

These diagrams are also useful for visually describing the differences in major ion chemistry in groundwater flow systems. New diagram has been proposed for geochemical data presentations (Chadha 1999). The proposed diagram is a modification of Piper diagram (Piper 1953) with a view to extend its applicability in representing water analysis in the possible simplest way. In the present study, the groundwater of the study area has been classified as per Chadha's diagram (Chadha 1999) and to identify the hydrochemical processes. The diagram is a somewhat modified version of Piper trilinear diagram (Piper 1944) and the expanded Durov diagram (Durov 1948).

In this diagram the difference in mill equivalent percentage between alkaline earths $(\mathrm{Ca}+\mathrm{Mg})$ and alkali metals $(\mathrm{Na}+\mathrm{K})$, expressed as percentage reacting values, is plotted on the $\mathrm{X}$ axis and the difference in mill equivalent percentage between weak acidic anions $\left(\mathrm{CO}_{3}+-\right.$ $\left.\mathrm{HCO}_{3}\right)$ and strong acidic anions $\left(\mathrm{Cl}+\mathrm{SO}_{4}\right)$ is plotted on the $Y$ axis. The mill equivalent percentage differences between alkaline earth and alkali metals and between weak acidic anions and strong acidic anions would plot in one of the four possible sub-fields of the diagram. The square or rectangular field describes the overall character of the water. In order to define the primary character of water, the rectangular field is divided into eight sub-fields, each of which represents a water type: (1) alkaline earths exceed alkali metals; (2) alkali metals exceed alkaline earths; (3) weak acidic anions exceed strong acidic anions; (4) strong acidic anions exceed weak acidic anions; (5) alkaline earths and weak acidic anions exceed both alkali metals and strong acidic anions, respectively; such water has temporary hardness; (6) alkaline earths exceed alkali metals and 

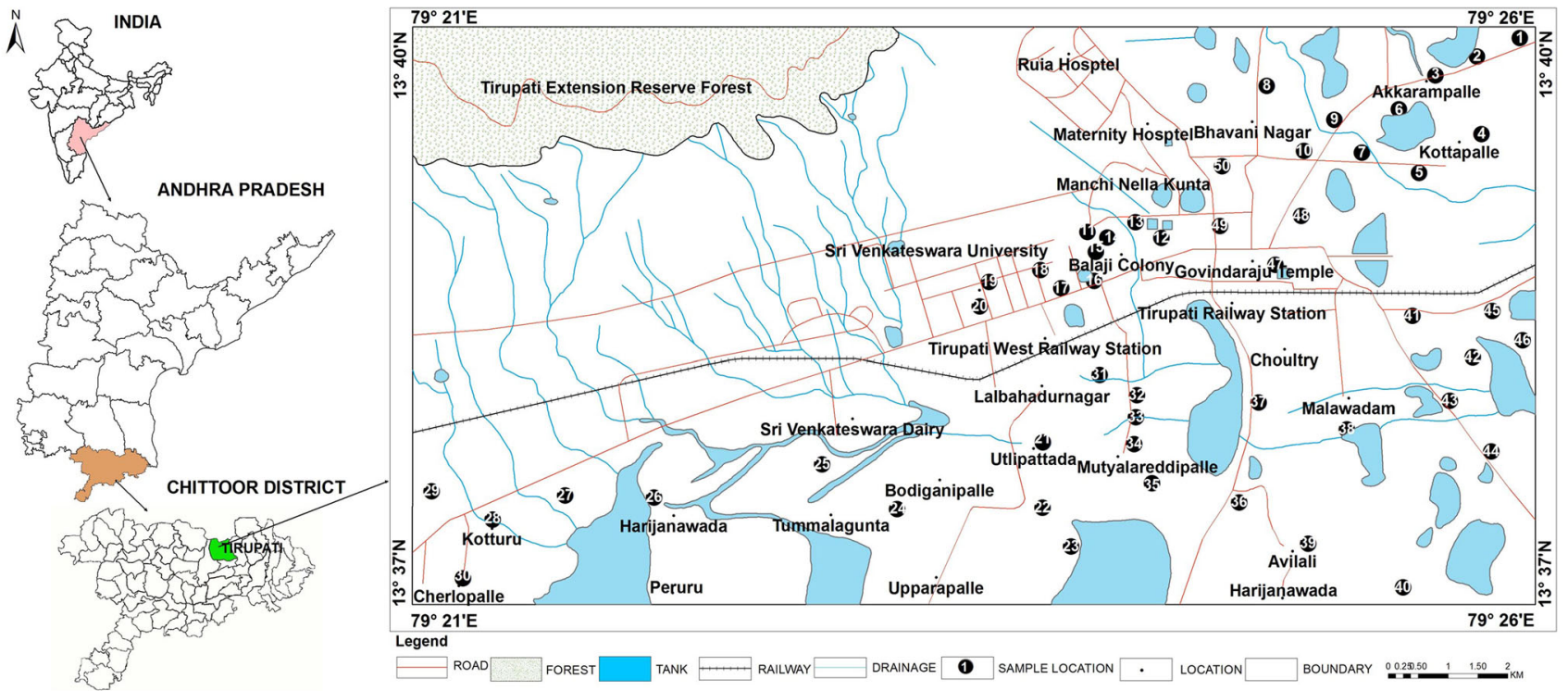

Fig. 1 Map of the study area with water sample locations

strong acidic anions exceed weak acidic anions; such water has permanent hardness; (7) alkali metals exceed alkaline earths and strong acidic anions exceed weak acidic anions; (8) alkali metals exceed alkaline earths and weak acidic anions exceed strong acidic anions.

The minimum, maximum and average values of water quality parameters are given in Table 1 .

\section{Results and discussion}

\section{Groundwater chemistry}

The minimum and maximum values of $\mathrm{pH}$ and electrical conductivity (EC) of groundwaters are ranging from 6.8 to 8.5 and 400 to $2550 \mu \mathrm{mhos} / \mathrm{cm}$, respectively. Total dissolved solids (TDS) in the study area vary between 256.0 and $1632.0 \mathrm{mg} / \mathrm{l}$. In the present study about $50 \%$ of the studied wells, the TDS values have exceeded the the maximum permissible limit. The total hardness $\left(\right.$ as $\left.\mathrm{CaCO}_{3}\right)$ from 116 to $752 \mathrm{mg} / \mathrm{l}$.

In the study area, the $\mathrm{Na}$ and $\mathrm{K}$ concentrations in groundwater range from 24 to 150 and 2 to $14 \mathrm{mg} / \mathrm{l}$, respectively. The concentrations of $\mathrm{Ca}$ and $\mathrm{Mg}$ ranges from 25 to 162 and 11 to $81 \mathrm{mg} / \mathrm{l}$. The $F$ content varies from 0.10 to $0.50 \mathrm{mg} / \mathrm{l}$. The concentrations of $\mathrm{CO}_{3}$ and $\mathrm{HCO}_{3}$ ions found in the groundwater samples of study area are ranged from 2 to 9 and 32 to $535 \mathrm{mg} / \mathrm{l}$, respectively. The concentration of $\mathrm{Cl}$ ranges from 43 to $461 \mathrm{mg} / \mathrm{l}$. The alkalinity varies from 30.7 to $400.5 \mathrm{mg} / \mathrm{l}$ and the $\mathrm{SO}_{4}$ varies from 7 to $94 \mathrm{mg} / \mathrm{l}$. The abundance of the major ions in groundwaters of the study area is as follows:
$\mathrm{Na}^{+}>\mathrm{Ca}^{2+}>\mathrm{Mg}^{2+}>\mathrm{K}^{+}$and $\mathrm{HCO}_{3}^{-}>\mathrm{Cl}^{-}>\mathrm{SO}_{4} 2^{-}>\mathrm{CO}_{3} 2^{-}>F^{-}$

The chemical data of the groundwater samples from Tirupati area are plotted in Gibbs diagram which shows that most of the samples of the study area fall in the category of precipitation dominance and the rock dominance, indicating that this process is also responsible for the groundwater chemistry. So the precipitation is the main processes which contribute ions to the groundwater of the study area.

The Chada's diagram can be used to study the various hydro chemical processes, such as base cation exchange, cement pollution, mixing of natural waters, sulphate reduction, saline water and other related hydro chemical problems (Chadha 1999). Results of analyses were plotted on the proposed diagram to test its applicability for geochemical classification of groundwater and to study hydrochemical processes (Fig. 2). It is evident from the results, that about $60 \%$ samples fall in $\mathrm{Ca}-\mathrm{Mg}-\mathrm{Cl}$ Water Type and the remaining $40 \%$ samples fall in Group Ca$\mathrm{Mg}-\mathrm{HCO}_{3}$ water type.

\section{Mechanism controlling groundwater chemistry}

Gibbs diagrams (1970), representing the ratios of $\left(\mathrm{Na}^{+}\right.$ $\left.+\mathrm{K}^{+}\right) /\left(\mathrm{Na}^{+}+\mathrm{K}^{+}+\mathrm{Ca}^{2+}\right)$ and $\mathrm{Cl}^{-} /\left(\mathrm{Cl}^{-}+\mathrm{HCO}_{3}{ }^{-}\right)$as a function of TDS, are widely employed to assess the functional sources of dissolved chemical constituents, such as precipitation dominance, rock dominance and evaporation dominance. Reactions between groundwater and the aquifer constituent minerals have a significant role on water 
Table 1 Minimum, maximum, standard deviation and average values of different constituents of water samples

\begin{tabular}{|c|c|c|c|c|c|c|}
\hline P. no. & Constituents & Min & Max & Average & St. dv. & St. error \\
\hline 1 & Calcium (Ca) (mg) & 25.0 & 162.0 & 84.0 & 31.8 & 4.5 \\
\hline 2 & Magnesium (Mg) (mg/l) & 11.0 & 81.0 & 34.7 & 16.9 & 2.4 \\
\hline 3 & Sodium $(\mathrm{Na})(\mathrm{mg} / \mathrm{l})$ & 24.0 & 150.0 & 93.4 & 35.6 & 5.0 \\
\hline 4 & Potassium $(\mathrm{K})(\mathrm{mg} / \mathrm{l})$ & 2.0 & 14.0 & 3.7 & 2.8 & 0.4 \\
\hline 5 & Bicarbonate $\left(\mathrm{HCO}_{3}\right)(\mathrm{mg} / \mathrm{l})$ & 32.0 & 535.0 & 282.2 & 144.6 & 20.4 \\
\hline 6 & Carbonate $\left(\mathrm{CO}_{3}\right)(\mathrm{mg} / \mathrm{l})$ & 2.0 & 9.0 & 4.4 & 2.1 & 0.3 \\
\hline 7 & Sulphate $\left(\mathrm{SO}_{4}\right)(\mathrm{mg} / \mathrm{l})$ & 7.0 & 94.0 & 52.4 & 25.8 & 3.6 \\
\hline 8 & Chloride $(\mathrm{Cl})(\mathrm{mg} / \mathrm{l})$ & 43.0 & 461.0 & 189.6 & 97.6 & 13.8 \\
\hline 9 & Fluoride $(\mathrm{F})(\mathrm{mg} / \mathrm{l})$ & 0.1 & 0.5 & 0.3 & 0.09 & 0.1 \\
\hline 10 & Total dissolved solids (mg/l ) & 256.0 & 1632.0 & 948.5 & 368.8 & 52.2 \\
\hline 11 & Hardness as $\mathrm{CaCO}_{3}(\mathrm{mg} / \mathrm{l})$ & 116.0 & 752.0 & 385.7 & 148.1 & 20.9 \\
\hline 12 & Alkalinity as $\mathrm{CaCO}_{3}(\mathrm{mg} / \mathrm{l})$ & 30.7 & 400.5 & 213.9 & 106.7 & 15.1 \\
\hline 13 & $\mathrm{pH}$ & 6.8 & 8.5 & 7.8 & 0.35 & 0.1 \\
\hline 14 & Specific conductance $\left(\mu \mathrm{mhos} \mathrm{cm}^{-1}\right)$ & 400.0 & 2550.0 & 1482.0 & 576.2 & 81.5 \\
\hline 15 & Non-carbonate hardness $(\mathrm{NCH})$ as $\mathrm{CaCO}_{3}(\mathrm{mg} / \mathrm{l})$ & -137.9 & 524.0 & 114.8 & 124.3 & 17.6 \\
\hline 16 & Sodium adsorption ratio (SAR) & 0.7 & 3.5 & 2.2 & 0.7 & 0.1 \\
\hline 17 & adjusted SAR (adj. SAR) & 1.4 & 7.9 & 4.9 & 1.90 & 0.3 \\
\hline 18 & Percent sodium (PS) $(\%)$ & 16.8 & 49.4 & 36.8 & 8.2 & 1.2 \\
\hline 19 & Potential salinity (PS) $\left(\right.$ meq $\left.1^{-1}\right)$ & 1.3 & 13.9 & 5.9 & 2.9 & 0.4 \\
\hline 20 & Residual sodium carbonate (RSC) (meq $1^{-1}$ ) & -10.5 & 2.8 & -2.3 & 2.5 & 0.4 \\
\hline 21 & Permeability index (PI) $(\%)$ & 32.6 & 75.4 & 56.7 & 9.9 & 1.4 \\
\hline 22 & Kelley's ratio & 0.2 & 0.9 & 0.6 & 0.2 & 0.1 \\
\hline 23 & Magnesium ratio (\%) & 20.8 & 66.7 & 40.1 & 11.8 & 1.7 \\
\hline 24 & Calcium to magnesium molar ratio & 0.5 & 0.70 & 1.7 & 0.8 & 0.1 \\
\hline 25 & Indices of base exchange (IBE) CAII & -1.65 & 0.5 & 0.09 & 0.42 & 0.06 \\
\hline 26 & Indices of base exchange (IBE) CAIII & -0.37 & 3.21 & 0.34 & 0.65 & 0.09 \\
\hline 27 & Gibbs ratio I & 0.16 & 0.95 & 0.53 & 0.20 & 0.03 \\
\hline 28 & Gibbs ratio II & 0.29 & 0.68 & 0.49 & 0.09 & 0.01 \\
\hline
\end{tabular}

quality. Further, these studies are useful to understand the genesis of groundwater.

To understand the groundwater interaction, with precipitation, rock and evaporation, as mechanisms controlling the water chemistry (Gibbs 1970), the ratios $\mathrm{Na}^{+}+\mathrm{K}^{+} ; \mathrm{Na}^{+}+\mathrm{K}^{+}+\mathrm{Ca}^{2+}$ and $\mathrm{Cl}^{-}: \mathrm{Cl}^{-}+\mathrm{HCO}_{3}{ }^{-}$ computed from the ionic concentration of groundwater of the Tirupati area are plotted against TDS (Fig. 3). Based on Gibbs diagram, there are three major mechanisms that regulate the chemistry of the groundwater: (1) evaporation dominance, (2) precipitation dominance and (3) rock dominance.

It is a plot of $\left(\mathrm{Na}^{+}+\mathrm{K}^{+}\right) /\left(\mathrm{Na}^{+}+\mathrm{K}^{+}+\mathrm{Ca}^{2+}\right)$ versus $\log \mathrm{TDS}$ and $\mathrm{CI}^{-} /\left(\mathrm{CI}^{-}+\mathrm{HCO}_{3}{ }^{-}\right)$versus log TDS. Figure 3 shows that, majority of them about 34 samples fall under precipitation dominance area $(68 \%)$ and remaining 16 samples $(32 \%)$ fall under rock dominance area.

This study reveals that both precipitation and rock weathering (e.g., granitic rocks) are responsible for the groundwater chemistry. Gibbs ratio I values in the present study varies from 0.16 to 0.95 with a average value of 0.53 and Gibbs ratio II values varies from 0.29 to 0.68 with a average value of 0.49 .

\section{Sodium adsorption ratio (SAR)}

An important chemical parameter for judging the degree of suitability of water for irrigation is sodium content or alkali hazard, which is expressed as the sodium adsorption ratio (SAR) (Asadollahfardi et al. 2012).

The SAR parameter is obtained from the following equation

$\mathrm{SAR}=\frac{\mathrm{Na}^{+}}{\left[\left(\mathrm{Ca}^{+}+\mathrm{Mg}^{2+}\right) / 2\right]^{1 / 2}}$

It measures the potential dangers posed by excessive sodium in irrigation water (Alagbe 2006). The sodium hazard or SAR is expressed in terms of classification of irrigation water as low $(\mathrm{S} 1:<10)$, medium (S2: 10-18), high (S3: 18-26) and very high (S4: >26). A high SAR 
Fig. 2 Chadha's diagram (modified Piper diagram)

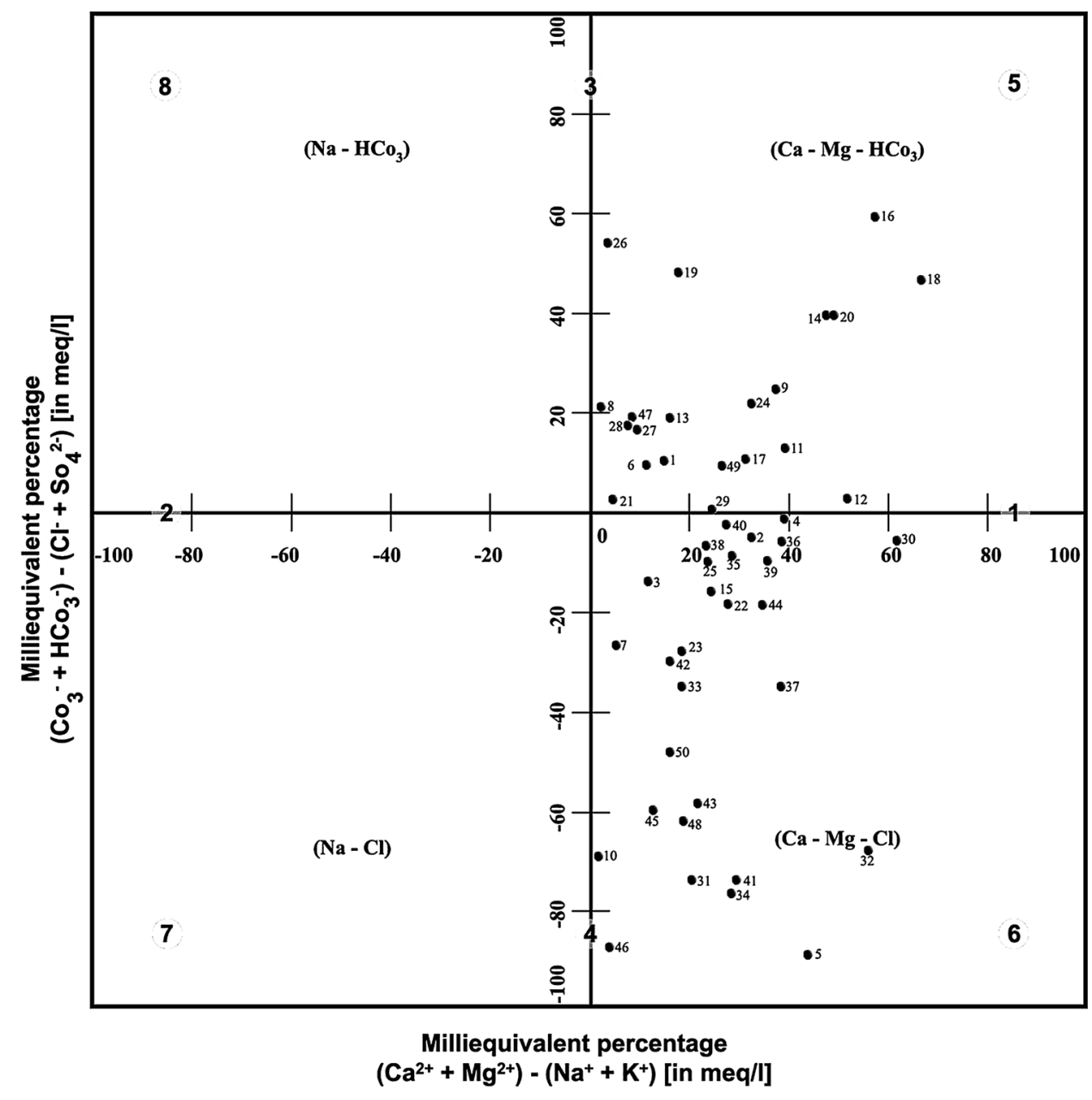

value implies a hazard of sodium (alkali) replacing $\mathrm{Ca}^{2+}$ and $\mathrm{Mg}^{2+}$ in the soil through a cation exchange process that damages soil structure, mainly permeability, and which ultimately affects the fertility status of the soil and reduces crop yield (Gupta 2005).

The level of salinity and SAR, adsorption of $\mathrm{Na}^{+}$by soils and clay minerals is greater at higher $\mathrm{Mg}: \mathrm{Ca}$ ratios. This is because the bonding energy of $\mathrm{Mg}^{2+}$ is less than that of $\mathrm{Ca}^{2+}$, allowing more $\mathrm{Na}^{+}$adsorption and it happens when the ratio exceed 4.0 (Michael 1992). It is reported that soil containing high levels of exchangeable $\mathrm{Mg}^{2+}$ causes an infiltration problem (Ayers and Westcot 1985). The SAR values of the ground water samples in the study area varied from 0.7 to 3.5 . The SAR values of the water samples of the study area are less than 10, and are classified as excellent for irrigation.

\section{Adjusted SAR}

The high concentration of sodium in irrigation water may negatively affect the soil structure and decrease the soil hydraulic conductivity in fine-textured soil. The degree to which sodium will be absorbed by a soil is a function of the amount of sodium to divalent cations $(\mathrm{Ca}$ and $\mathrm{Mg})$ and is regularly stated by the sodium adsorption ratio (SAR) (Bouwer and Idelovitch 1987). The SAR is a general water quality index that indicates the percentage of sodium in the water and function of the ratio of sodium to divalent cations such as $\mathrm{Ca}$ and $\mathrm{Mg}$.

$\operatorname{adjSAR}=\mathrm{SAR}[9.4-p(\mathrm{k} 2-\mathrm{kc})+p(\mathrm{Ca} 2++\mathrm{Mg} 2+)+p(\mathrm{Alk})]$

where $p \mathrm{k} 2=$ negative logarithm of the second dissociation constant for carbonic acid; $p \mathrm{kc}=$ solubility constant for calcite; and $p=$ negative logarithm of ion concentration (meq/l). The amount of $\mathrm{p}(\mathrm{k} 2-\mathrm{kc}), p\left(\mathrm{Ca}^{2+}+\mathrm{Mg}^{2+}\right)$ and $p$ (Alk) related to $\mathrm{Ca}^{2+}+\mathrm{Mg}^{2+}+\mathrm{Na}^{+}, \mathrm{Ca}^{2+}+\mathrm{Mg}^{2+}$ and $\mathrm{CO}_{3}{ }^{-}+\mathrm{HCO}_{3}{ }^{-}$respectively, can be found in Bouwer (1993).

The adjusted SARadj value typically is computed, which take into account the effects of rainfall. Sodium also has adverse effects on the crops such as leaf burn in almond, avocado, and stone fruits (Bouwer and Idelovitch 

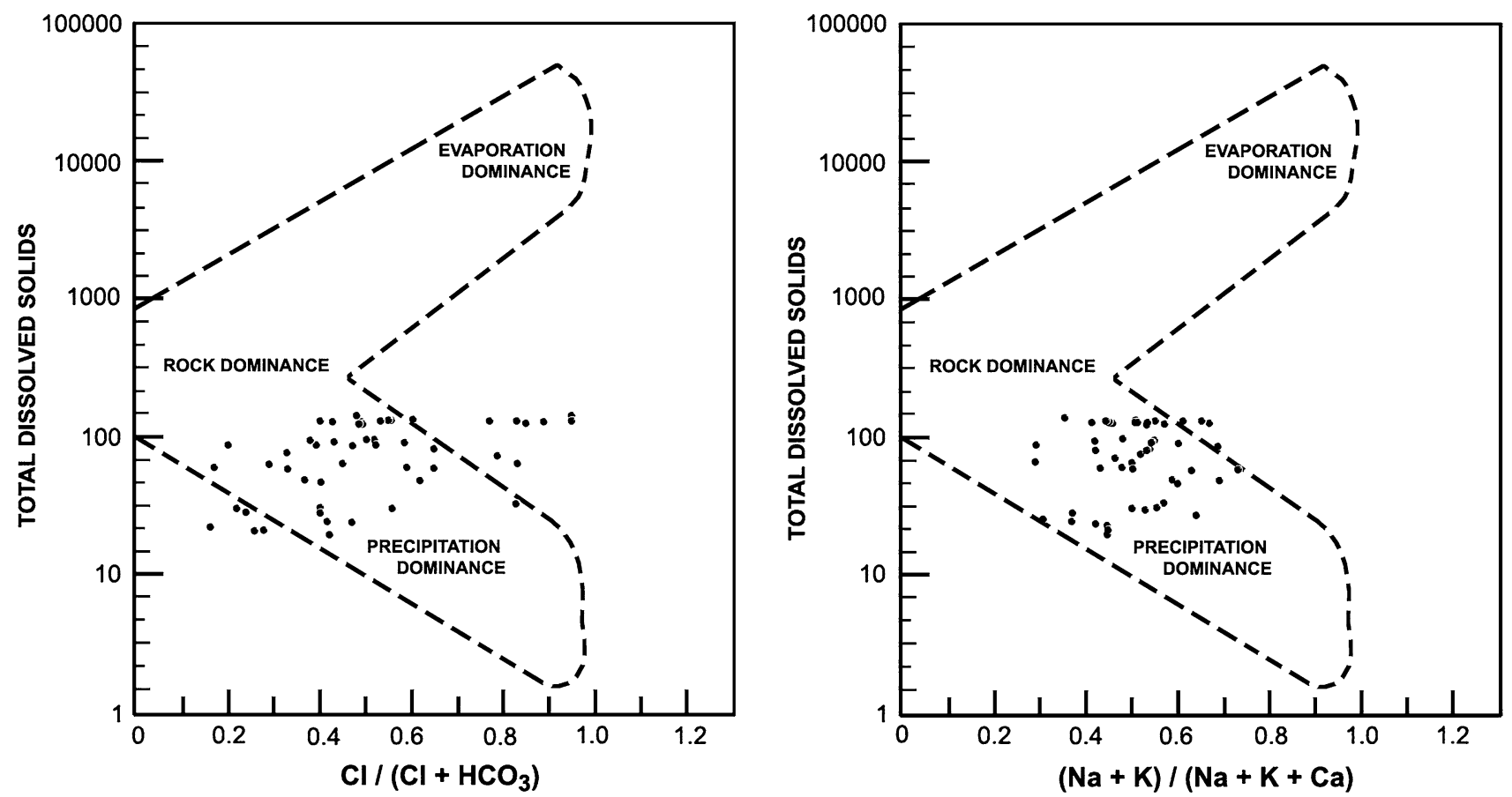

Fig. 3 Mechanism controlling the chemistry of groundwater (after Gibbs 1970)

1987). It is reported that if the SARadj is below 3 , it is good for irrigation and shows increasing problems if the SAR is between 3 and 9. Further, if the SAR is above 9, there are severe problems (Ayers and Tanji 1981). In the present study adjusted SAR values are ranging from 1.4 to 7.9 with a mean value of 4.9 .

\section{USSL classification}

The US Salinity Laboratory's diagram is used widely for rating irrigation water where SAR is plotted against EC (Richards 1954). Here, SAR is an index of sodium hazard and EC is an index of salinity hazard (Parimala Renganayaki and Elango 2013). The SAR and EC values of the water samples in the study area were plotted in the graphical diagram (Fig. 4). Majority of the water samples (about $72 \%$ ) in the study area falling in C3S1 (EC $<2250 \mu \mathrm{mhos} / \mathrm{cm}$ ) high salinity with low sodium). About $22 \%$ of the samples are falling in C2S1 (EC $<750 \mu \mathrm{mhos} / \mathrm{cm}$ medium salinity with low sodium) and 3 samples are falling in C4S1 $(\mathrm{EC}>2250 \mu \mathrm{mhos} / \mathrm{cm}$ very high salinity with low sodium. (10, 3 and, 46).

Wilcox's diagram (1948) is especially implemented to classify groundwater quality for irrigation. Figure 5 can provide the apparent situation to understand the suitability of water for irrigation. $60 \%$ of all samples were good to permissible; and $22 \%$ were excellent to good categories. Remaining $18 \%$ of samples are falling under Doubtful to unsuitable category.

\section{Non-carbonate hardness $(\mathrm{NCH})$}

Hardness of water relates to the reaction with soap as $\mathrm{Ca}$ and $\mathrm{Mg}$ ions precipitate soap. Hardness is expressed as $\mathrm{mg} /$ 1 of $\mathrm{CaCO}_{3}$. If the hardness as $\mathrm{CaCO}_{3}$ exceeds the difference between the alkalinity as $\mathrm{CaCO}_{3}$ and hardness as $\mathrm{CaCO}_{3}$, it is termed as Non-Carbonate Hardness. It is also called permanent hardness. From the Table 1, it can be delineated that the $\mathrm{NCH}$ values ranged from -137.9 to 524.0 with an average of 114.8 .

\section{Permeability index}

It occurs when normal infiltration rate of soil is appreciably reduced and hinders moisture supply to crops which is responsible for two most water quality factors as salinity of water and its sodium content relative to $\mathrm{Ca}$ and $\mathrm{Mg}$. Highly saline water increases the infiltration rate.

Doneen (1964) defined permeability index (PI) as:

$\mathrm{PI}=\frac{\mathrm{Na}^{+}+\sqrt{ } \mathrm{HCO}_{3}^{-}}{\left(\mathrm{Ca}^{2+}+\mathrm{Mg}^{2+}+\mathrm{Na}^{+}\right)} \times 100$

In the study area, the PI values varied from 32.6 to 75.4 .

\section{Kelly's ratio}

Kelley's ratio was used to classify the irrigation water quality (Kelly 1940), which is the level of $\mathrm{Na}^{+}$measured 


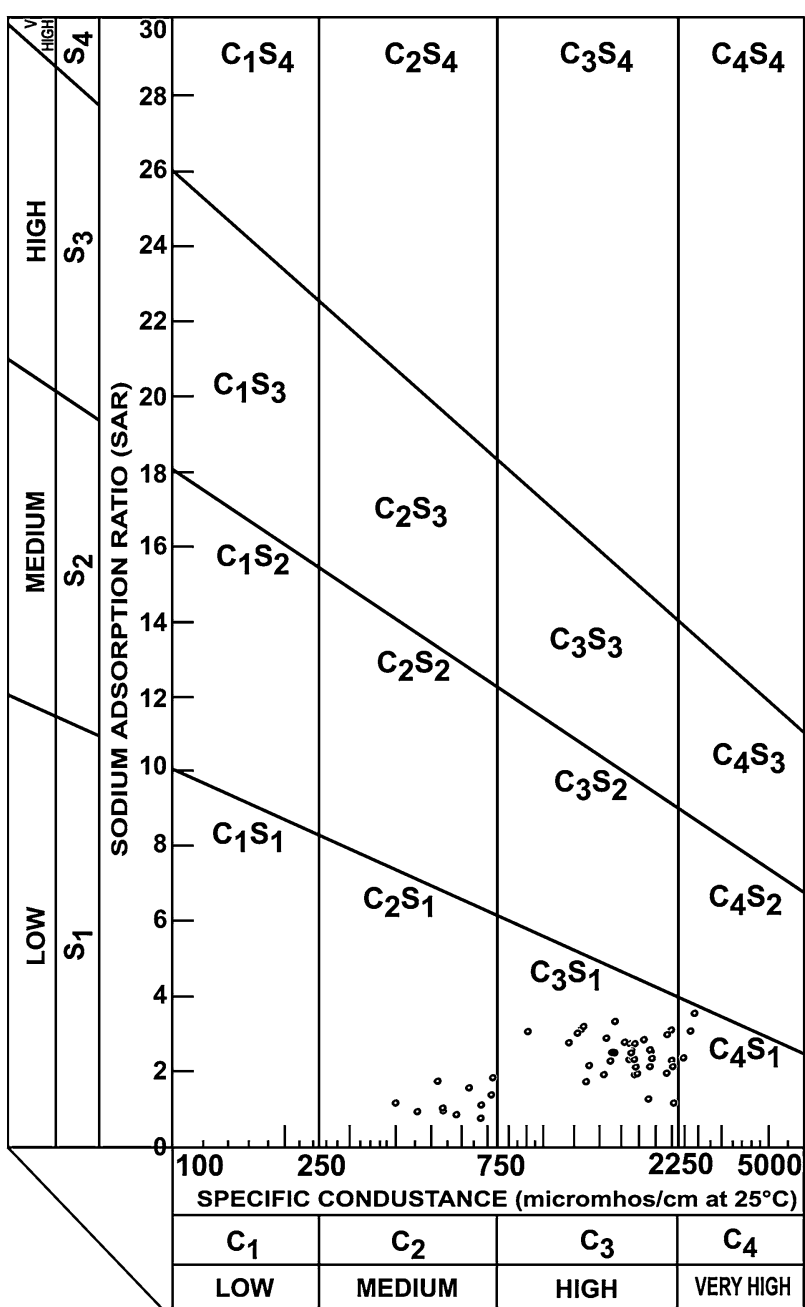

Fig. 4 The quality of water samples in relation to salinity and sodium hazard (after US salinity Laboratory 1954)

against $\mathrm{Ca}$ and $\mathrm{Mg}$. The formula for calculating the Kelley's ratio is as follows:Kelly's ratio (KR) (Kelly 1963) described as:

$\mathrm{KR}=\frac{\mathrm{Na}^{+}}{\left(\mathrm{Ca}^{2+}+\mathrm{Mg}^{2+}\right)}$,

Kelly's ratios for all the groundwater samples are calculated and it lies between 0.2 and 0.9 with a mean value of 0.6. Kelly's ratio value less than one is suitable for irrigation According to this classification, majority of the samples are suitable for irrigation.

\section{Magnesium hazard}

Generally, $\mathrm{Ca}^{2+}$ and $\mathrm{Mg}^{2+}$ maintain a state of equilibrium in most waters. More $\mathrm{Mg}^{2+}$ in waters adversely affects the crop yield. In this study magnesium hazard was evaluated by two following methods including "magnesium ratio" and "Ca to Mg molar ratio". From the Table 1, it is seen

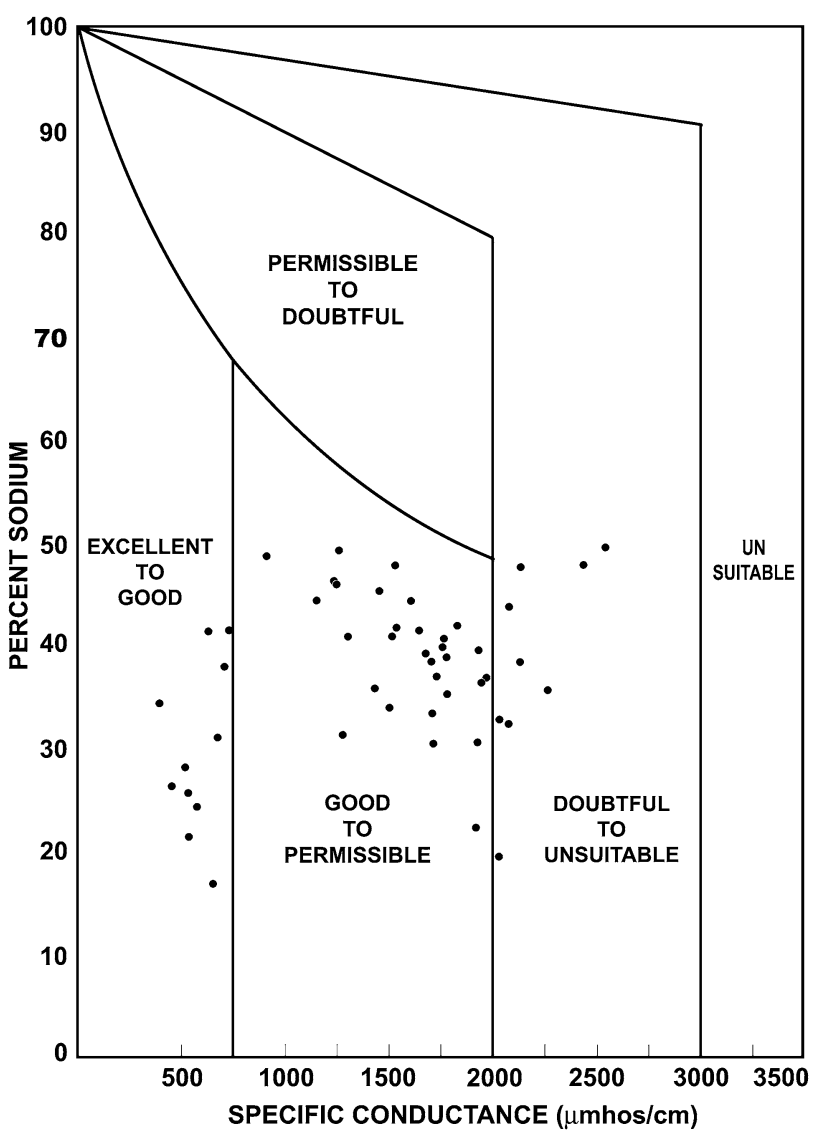

Fig. 5 The quality of water in relation to electrical conductivity and percent sodium (Wilcox diagram)

that the magnesium ratio $\{\mathrm{Mg}$ ratio $=[\mathrm{Mg} /(\mathrm{Ca}+\mathrm{Mg})] \times$ $100\}$ has varied from 20.8 to 66.7 with an average value of 40.1. In this study nearly $22 \%$ of samples exceeeding permissible limits, would adversely affect the crop yield as turn the soils more alkaline (Paliwal 1972).

\section{Residual sodium carbonate}

Residual sodium carbonate (RSC) index of irrigation/soil water is used to indicate the alkalinity hazard of soil. RSC index is used to find the suitability of water for irrigation in clay soils which has high cation exchange capacity. When dissolved sodium in comparison with dissolved $\mathrm{Ca}$ and $\mathrm{Mg}$ is high in water, clay soil swells or undergoes dispersion which drastically reduces its infiltration capacity. The RSC can be calculated as follows (Raghunath 1987).

$\mathrm{RSC}=\mathrm{CO}_{3}^{2-}+\mathrm{HCO}_{3)}^{-}-\left(\mathrm{Ca}^{2+}+\mathrm{Mg}^{2+}\right)$

all the concentrations are expressed in meq/l. The classification of irrigation water based on the RSC values shows minimum value of -10.5 and maximum value of 2.8 . 


\section{Chloroalkaline indices}

Chloroalkaline indices I and II are used to understand the chemical reactions in which ion exchange takes place (Swarna Latha and Nageswara Rao 2012). Ions in groundwater exchange with the ions of its aquifer environment during the periods of residence and movement. They are calculated as follows:

$$
\begin{aligned}
& \text { CAI-I }=\frac{\mathrm{Cl}^{-}\left(\mathrm{Na}^{+}+\mathrm{K}^{+}\right)}{\mathrm{Cl}^{-}}, \\
& \text {CAI-II }=\frac{\mathrm{Cl}^{-}\left(\mathrm{Na}^{+}+\mathrm{K}^{+}\right)}{\left(\mathrm{SO}_{4}^{2-}+\mathrm{HCO}_{3}^{-}+\mathrm{CO}_{3}^{2-}+\mathrm{NO}_{3}^{-}\right)}
\end{aligned}
$$

where the concentration of ions are in meq/l.

Both the above indices are negative if there is an exchange between $\mathrm{Ca}$ or $\mathrm{Mg}$ in the groundwater with $\mathrm{Na}$ and $\mathrm{K}$ in the aquifer material, and both these indices will be positive if there is a reverse ion exchange (Schoeller 1977).

From the Table 1, it can be put forth that the CAI- I values range from -1.65 to 0.70 and CAI- II values vary from -0.37 to 3.21 . From these values it can be interpreted that some of the samples in the study area fall into negative zones and some fall into positive zones. They indicate the exchange of $\mathrm{Na}$ and $\mathrm{K}$ from the water with $\mathrm{Mg}$ and $\mathrm{Ca}$ of the rocks which are mainly of granitic origin (Nagaraju et al. 2015).

\section{Sodium percentage $(\mathrm{Na} \%)$}

Sodium concentration is an important factor in classifying the water for irrigation purposes because it can react with soil resulting in the clogging of particles, thereby, reducing the permeability of water and respiratory gases (Todd and Mays 2005; Sundaray et al. 2009). Sodium concentration in groundwater is a very important parameter in determining the irrigation quality. Todd (1980) defined soluble sodium percentage (SP) as:

$\mathrm{SP}=\frac{\left(\mathrm{Na}^{+}+\mathrm{K}^{+}\right)}{\mathrm{Ca}^{2+}+\mathrm{Mg}^{2+}+\mathrm{Na}^{+}+\mathrm{K}^{+}} \times 100$

where all the ionic concentrations are in meq/l.

The determined values of sodium percentage lies between 16.8 and 49.4 (Table 1). In irrigation water if the sodium concentration became high, sodium ions tends to replace the $\mathrm{Mg}^{2+}$ and $\mathrm{Ca}^{2+}$ ions by absorbed clay particles. This exchange process in soil reduces the permeability and eventually decreases the internal drainage of the soil. Hence, water and air circulation is restricted during wet conditions, and such soils become hard in dry conditions (Collins and Jenkins 1996; Saleh et al. 1999; Subramani et al. 2005). Dissolution-precipitation of secondary carbonates, chemical weathering of rock forming minerals, and ion exchange between water and clay minerals are some of the general reactions responsible for the geochemical constitution of the groundwater. Dissolution of both primary silicate and carbonate minerals may lead to the increase of $\mathrm{Ca}, \mathrm{Na}, \mathrm{Mg}$, and $\mathrm{HCO}_{3}$, which increase the value of pH (Rouabhia et al. 2011). The higher concentrations of $\mathrm{Na}$ and $\mathrm{Cl}$ in groundwater are probably controlled by rock water interaction most likely by feldspar weathering. The low sodium in some of the samples is due to the ion exchange with $\mathrm{Ca}$ and $\mathrm{Mg}$ in clays, which is common in saline groundwater (Cartwright et al. 2004).

\section{Conclusion}

Generally, the groundwater quality of the area is hard, fresh and slightly alkaline in nature. The dominant groundwater type was $\mathrm{Ca}-\mathrm{Mg}-\mathrm{HCO}_{3}$ type and mixed $\mathrm{Ca}-\mathrm{Mg}-\mathrm{Cl}$ type. The major ions in most of the locations were found to be within in WHO permissible limit for drinking water. The groundwater geochemistry reveals that the present status of groundwater samples collected in the study area is better for drinking and irrigation purposes except few samples, which are crossing the allowable limits of World Health Organization (WHO) standards.

Sodium is the most dominant ion, but the common trend was $\mathrm{Na}$ and $\mathrm{Ca}$ are the dominant cations with $\mathrm{Cl}$ and $\mathrm{HCO}_{3}$ as the dominant anions. Even though the majority of samples are within the permissible limits, few are crossing it and some are very close to the allowable limits which indicate there may be a deterioration of water quality in near future. This was because of the interaction of the ground water with sewage and intensive agricultural practices.

The $\mathrm{Ca}$ present in groundwaters is derived from $\mathrm{Ca}$ rich minerals like feldspars, pyroxenes and amphiboles from granitic rocks. The major source of $\mathrm{Mg}$ in the groundwater is due to ion exchange of minerals in rocks and soils by water. Considering the gross salinity, total hardness, $\mathrm{pH}$, and other irrigation parameters, majority of the groundwater samples shows a fresh to highly saline, hard to very hard, slightly alkaline, and excellent to permissible nature, respectively. The calculated chemical parameters such as $\mathrm{Na} \%$, SAR, RSC, PI, MR, and KR indicate that the water in the study area can be used for irrigation with improved drainage facilities. High values of electrical conductivity and high concentration of the chemical constituents such as $\mathrm{Na}^{+}, \mathrm{Cl}^{-}, \mathrm{SO}_{4}{ }^{2-}$ and $\mathrm{HCO}_{3}{ }^{-}$present in the groundwater may be due to dissolution of mineral phases and may be under the influence of anthropogenic activities such as interaction with sewage from urban and industrial waste, massive usage of fertilizers, and intense agricultural practices. Gibbs plots confirm that the most of the samples of 
the study area fall in the category of precipitation dominance and the rock dominance, indicating that this process is also responsible for the groundwater chemistry. So the precipitation is the main processes which contribute ions to the groundwater of the study area. Further, the rural to urban migration in Tirupati town increases urban expansion which in turn leads to several groundwater quality problems.

Open Access This article is distributed under the terms of the Creative Commons Attribution 4.0 International License (http:// creativecommons.org/licenses/by/4.0/), which permits unrestricted use, distribution, and reproduction in any medium, provided you give appropriate credit to the original author(s) and the source, provide a link to the Creative Commons license, and indicate if changes were made.

\section{References}

Alagbe SA (2006) Preliminary evaluation of hydrochemistry of the Kalambaina formation, Sokoto Basin, Nigeria. Environ Geol 51:39-45

Alley WM, Reilly TE, Franke OL (1999) Sustainability of groundwater resources: US Geological Survey Circular 1186, p 79

Alshikh A (2011) Analysis of heavy metals and organic pollutants of ground water samples of South Saudi. Life Sci J $8(4): 438-441$

APHA (2005) Standard methods for the examination of water and wastewater, 21st edn. American Public Health Association, Washington

Appelo CAJ, Postma D (1996) Geochemistry, groundwater and pollution. Balkema, Rotterdam, p 536

Asadollahfardi G, Taklify A, Ghanbari A (2012) Application of artificial neural network to predict TDS in Talkheh Rud River. J Irrig Drain Eng 138(4):363-370. doi:10.1061/(ASCE)IR.19434774.0000402

Ayers RS, Tanji KK (1981) Agronomic aspects of crop irrigation with wastewater, Pro Water Forum 81,1. ASCE, New York, pp 579-586

Ayers RS, Westcot DW (1985) Water quality for agriculture, irrigation and drainage. Paper No. 29. Food and Agriculture Organization of the United Nations, Rome, Italy, pp 1-117

Bouwer H (1993) "Urban and agricultural competition for water, and water reuse." Internatl Jour of Water Resources Dev. doi:10. $1080 / 07900629308722570$

Bouwer H, Idelovitch E (1987) Quality requirement for irrigation with sewer water. J Irrig Drain Eng 113(4):516-535

Cartwright I, Weaver TR, Fulton S, Nichol C, Reid M, Cheng X (2004) Hydrogeochemical and isotopic constraints on the origins of dryland salinity, Murray Basin, Victoria, Australia. Appl Geochem 19:1233-1254

Chadha DK (1999) A proposed new diagram for geochemical classification of natural water and interpretation of chemical data. Hydrogeol J 7:431-439

Collins R, Jenkins A (1996) The impact of agricultural land use on stream chemistry in the Middle Hills of the Himalayas, Nepal. J Hydrol 185:71-86

Dilli Rani G, Suman M, Narasimha Rao C, Reddi Rani P, Prashanth VG, Prathibha R, Venkateswarlu P (2011) Assessment of ground water quality and its impact in and around Mangalam near Tirupathi, Andhra Pradesh, India. Curr World Environ 6(1):191-193
Doneen LD (1964) Water quality for agriculture. Department of Irrigation, University of California, Davis, $\mathrm{p} 48$

Durov SA (1948) Natural waters and graphic representation of their composition Dokl. Akad Nauk SSSR 59:87-90

Gibbs RJ (1970) Mechanisms controlling world water chemistry. Science 170:1081-1090

Gleick PH (1993) Water in crisis: a guide to the world's freshwater resources. Oxford University Press, Oxford, p 13

Gupta PK (2005) Methods in environmental analysis: water, soil and air. Agrobios, Jodhpur, pp 1-127

Hall MJ, Ellis JB (1985) Water quality problems of urban areas. Geo J 11:265-275

Hem JD (1985) Study and interpretation of the chemical characteristics of natural water. USGS Water Supply Paper, p 2254

Human Development Report of Andhra Pradesh (2007) Centre for economic and social studies. Publishers Vidya Graphics, Hyderabad

Janardhana raju N, Krishna Reddy TV (2006) Urban development and the Looming water crisis-a case study from Tirupati, South India. IAEG, The Geological Society of London, Paper No. 55, pp $1-5$

Jasmin I, Mallikarjuna P (2013) Physicochemical quality evaluation of groundwater and development of drinking water quality index for Araniar River Basin. Environ Monit Assess, Tamil Nadu. doi:10.1007/s10661-013-3425-7

Kankal NC, Indurkar MM, Gudadhe SK, Wate SR (2012) Water quality index of surface water bodies of Gujarat, India. Asian J Exp Sci 26(1):39-48

Kelly WP (1940) Permissible composition and concentration of irrigated waters. In: Proceedings of the ASCF, p 607

Kelly WP (1963) Use of saline irrigation water. Soil Sci 95(4):355-391

Michael AM (1992) Irrigation theory and practices. Vikash Publishing House Pvt Ltd, New Delhi, pp 686-740

Mishra UK, Tripathi AK, Tiwari S, Mishra A (2012) Assessment of quality and pollution potential of groundwater around Dabhaura area, Rewa District, Madhya Pradesh. Earth Sci Res Can 1(2):249-261

Nagaraju A, Suresh S, Killham K, Hudson-Edwards K (2006) Hydrogeochemistry of waters of Mangampeta a barite mining area, Cuddapah basin, Andhra Pradesh, India. Turkish J Eng Env Sci 30:203-219

Nagaraju A, Sunil Kumar K, Thejaswi A, Sharifi Z (2014) Statistical analysis of the hydrogeochemical evolution of groundwater in the Rangampeta area, Chittoor District, Andhra Pradesh, South India. Am J Water Res 2:63-70

Nagaraju A, Balaji,E, Thejaswi A, Sun L (2015) Quality evaluation of groundwater in Mulakalacheruvu area, Chittoor District, Andhra Pradesh, south india based on hydrogeochemistry. Fres Env Bull 24:4496-4503

Paliwal KV (1972) Irrigation with saline water. Water Technology Centre, Indian Agriculture Research Institute, New Delhi, p 198

Parimala Renganayaki S, Elango L (2013) Impact of recharge from a check dam on groundwater quality and assessment of suitability for drinking and irrigation purposes. Arab Jour Geosci. doi:10. 1007/s12517-013-0989-z

Piper AM (1944) A graphical procedure in the geochemical interpretation of water analysis. Trans Am Geophys Union 25:914-923

Piper AM (1953) A graphic procedure I the geo-chemical interpretation of water analysis, USGS Groundwater Note no. 12

Raghunath HM (1987) Groundwater, 2nd edn. Wiley Eastern Limited, New Delhi, p 563

Ravikumar P, Somashekar RK, Angami Mhasizonuo (2011) Hydrochemistry and evaluation of groundwater suitability for irrigation and drinking purposes in the Markandeya River basin, Belgaum 
District, Karnataka State, India. Environ Monit Assess 173:459-487

Richards LA (1954) Diagnosis and improvement of saline and alkali soils, 60. US Department of Agricultural Handbook, Washington DC, p 160

Rouabhia A, Baali F, Fehdi C, Abderrahmane B, Dajmel B (2011) Hydrogeochemistry of groundwaters in a semi-arid region El Ma El Abiod aquifer, Eastern Algeria. Arab J Geosci 4:973-982

Sadashivaiah C, Ramakrishnaiah CR, Ranganna G (2008) Hydrochemical analysis and evaluation of groundwater quality in Tumkur Taluk, Karnataka State, India. Int J Environ Res Public Health 5(3):158-164

Saha SK, Naznin S, Ahmed F (2006) A household based safe water intervention program for a slum area in Bangladesh. Asian $\mathrm{J}$ Water Environ Pollut 3(1):21-26

Saleh A, Al-Rowaiah F, Shehata M (1999) Hydrogeochemical processes operating within the main aquifers of Kuwait. J Arid Environ 42:195-209

Schoeller H (1977) Geochemistry of groundwater. Groundwater studies - an international guide for research and practice, 15. UNESCO, Paris, pp 1-18

Shrestha S, Kazama F (2007) Assessment of surface water quality using multivariate statistical techniques: a case study of the Fuji river basin, Japan. Environ Model Softw 22:464-475

Srinivas Y, Hudson Oliver D, Stanley Raj A, Chandrasekar N (2013) Evaluation of groundwater quality in and around Nagercoil town, Tamilnadu, India: an integrated geochemical and GIS approach. Appl Water Sci. doi:10.1007/s13201-013-0109-y
Stephen F, John C, Geert-Jan N, Andrea R (2013) Groundwater-a global focus on the 'local resource'. Curr Opin Environ Sustain 5:685-695

Subramani T, Elango L, Damodarasamy SR (2005) Groundwater quality and its suitability for drinking and agricultural use in Chithar River Basin, Tamil Nadu, India. Environ Geol 47:1099-1110

Sundaray SK, Nayak BB, Bhatta D (2009) Environmental studies on river water quality with reference to suitability for agricultural purposes: Mahanadi river estuarine system, India-a case study. Environ Monit Assess 155:227-243

Swarna Latha P, Nageswara Rao K (2012) An integrated approach to assess the quality of groundwater in a coastal aquifer of Andhra Pradesh, India. Environ Earth Sci 66:2143-2169

Todd DK (1980) Groundwater hydrology, 2nd edn. Wiley, New York, p 535

Todd DK, Mays LW (2005) Groundwater hydrology, 3rd edn. Wiley, Hoboken, p 656

Tripathi AK, Mishra UK, Mishra A, Dubey P (2012) Assessment of groundwater quality Gurh Tehseel, Rewa District Madhya Pradesh. India. Int J Sci Eng Res (IJSER) 3(9):1-12

Trivedy RK, Geol PK (1986) Chemical and biological methods for waste Pollution studies. Environ Publ, Karad, pp 35-96

WHO (2006) Burden of disease and cost effectiveness estimates. World Health Organization, Geneva

Wilcox LV (1948) The quality of water for irrigation use. US Department of Agriculture, Technical bulletin 1962, Washington DC, USA 